\title{
OBSZARY WIEJSKIE JAKO MIEJSCE POWSTAWANIA NOWYCH RUCHÓW SPOLECZNYCH. IMPLIKACJE TEORETYCZNE I EMPIRYCZNE ${ }^{1}$
}

\section{Streszczenie}

Możliwe jest stwierdzenie, że przemiany na obszarach wiejskich są odbiciem procesów, które zachodzą na poziomie całego społeczeństwa. Obserwacja z jednej strony rosnącej roli ruchów społecznych, zwłaszcza nowych ruchów społecznych, we współczesnych społeczeństwach, a z drugiej strony logiki zmian obszarów wiejskich, pozwala na wyznaczenie obszaru wspólnego tych, wydawałoby się, odległych od siebie zjawisk. Tekst próbuje wskazać na te procesy, które stanowią podłoże dla kształtowania się nowych ruchów społecznych na obszarach wiejskich i jednocześnie pokazać, że teorie ruchów społecznych są przydatne do analizy współczesnych obszarów wiejskich. Ma to dwojaką motywację: po pierwsze ruchy społeczne stanowią w nowoczesnym społeczeństwie jeden z głównych przejawów wyrażania się podmiotowości całych społeczeństw, jak również poszczególnych grup społecznych, stąd sam fakt podjęcia badań nad problematyką ruchów społecznych wydaje się być wart uwagi. Po drugie, zastosowanie teorii ruchów społecznych do analizy zachowań chłopów czy rolników, a więc mieszkańców wsi i obszarów wiejskich, był w literaturze światowej i polskiej stosowany zwykle w kontekście zbiorowych działań kontestacyjnych tej grupy społecznej. Nie znalazł on jednak szerszego zastosowania do analizy codziennego, niekontestacyjnego, w klasycznym tego słowa znaczeniu, działania wybranej kategorii mieszkańców obszarów wiejskich. Główne pytanie brzmi zatem: Jakie procesy czynią

* Dr hab.; e-mail: gforys@up.krakow.pl

Artykuł ten mógł powstać miedzy innymi dzięki środkom uzyskanym z Narodowego Centrum Nauki w ramach projektu badawczego OPUS 8, numer projektu 2014/15/B/HS6/01228. 
teorię nowych ruchów społecznych zdatną do analiz zachowań współczesnych mieszkańców obszarów wiejskich?

Słowa kluczowe: obszary wiejskie, agroturystyka, ruchy społeczne, dezaktywacja, schłopienie

\section{WPROWADZENIE}

Jakie procesy czynią teorię nowych ruchów społecznych zdatną do analiz zachowań zbiorowych części współczesnych mieszkańców wsi? Próba odpowiedzi na to pytanie będzie treścią rozważań przedstawionych $\mathrm{w}$ tym artykule. Tylko pozornie wydaje się ono wyważaniem już otwartych drzwi - teorie ruchów społecznych niejednokrotnie miały zastosowanie do analiz działań ludności wiejskiej, konkretnie chłopów i rolników, ale odnosiły się przede wszystkim do ich zachowań kontestacyjnych [por. np. Edelman 1999; Foryś 2008; Gorlach 2001; Halamska 1988; Jenkins 1982; Migdal 1974, 1975; Mooney 2004; Paige 1973; Reed 2004; Scott 1976, 1990; Shanin 1973; Wolf 1973]. Przywołane liczne opracowania na ten temat nie znajdują zastosowania do opisu świata życia codziennego współczesnych mieszkańców wsi, ani tym bardziej ich oporu względem presji systemu, używając pojęć Jürgena Habermasa. Jeśli przywołamy do tego tezę na temat „końca chłopów” we współczesnym rolnictwie krajów wysoko rozwiniętych, których działania kontestacyjne analizowano do tej pory najczęściej z wykorzystaniem teorii ruchów społecznych, to możemy dojść do wniosku, że teorie te są bezużyteczne w przywołanym tu kontekście. Nie jest to jednak prawda, co postaram się udowodnić w tym artykule.

Punktem wyjścia moich rozważań i swego rodzaju inspiracją jest twierdzenie, że współczesne obszary wiejskie w coraz mniejszym stopniu pozostaja w związku z działalnością rolniczą. Jak twierdzi Krzysztof Gorlach, „[...] drogi rozwoju rolnictwa oraz obszarów wiejskich zaczynają się niejako rozchodzić" [2004: 121-122]. Konsekwencją tego stanu rzeczy jest to, że współczesne obszary wiejskie, rozumiane jako odrębna całość społeczno-kulturowa z charakterystycznymi dla siebie cechami (mniejszą niż w mieście gęstością zaludnienia, obecnością specyficznego rodzaju aktywności zawodowej związanej z uprawą ziemi i hodowlą zwierząt, zanikającymi tradycyjnymi formami więzi społecznej, zanikającą kulturą wiejska, rozpadem etosu chłopskiego) zmieniają się w coraz większym stopniu pod wpływem całego zbioru czynników egzogennych i endogennych oddziałujących z różnych poziomów, od lokalnego po globalny. Można 
powiedzieć, że tak jak pod wpływem zmian modernizacyjnych przeobrażała się i zanikała tradycyjna wieś, ustępując miejsca obszarom wiejskim, tak obecnie obszary te w jeszcze większym stopniu pozostają pod wpływem wspomnianych procesów ${ }^{2}$.

Jednym z istotnych czynników endogennych odgrywających szczególną rolę w tych zmianach jest rolnictwo. Chociaż dynamika jego przeobrażeń niesie ze sobą wiele negatywnych konsekwencji zarówno dla samej produkcji rolnej, jak i dla społeczności wiejskich (takich jak np. chemizacja produkcji rolnej, znikanie z rynku małych gospodarstw rolnych, kurczenie się rynku pracy na wsi), to dzięki zmianom w rolnictwie obszary wiejskie otwierają się na coraz silniejsze wpływy pochodzące z zewnątrz. Polegają one między innymi na przenikaniu w ich obręb nowoczesnych technologii produkcji rolnej, co zmienia strukturę zawodową mieszkańców wsi i ogranicza obecność działalności rolniczej, ale pośrednio również wprowadza na wieś wartości, normy i sposoby zachowania charakterystyczne dla miasta. Można powiedzieć zatem o obszarach wiejskich, że „coraz bardziej stają się one po prostu jednym z elementów nowoczesnego, a z czasem także ponowoczesnego społeczeństwa" [Gorlach 2004: 48].

Mając na uwadze fakt, że obszary wiejskie są dziś otwarte na wpływy z zewnątrz, warto się zastanowić, czy w związku z tym poszerza się zakres zjawisk zachodzących na tych obszarach wymagających eksploracji i wyjaśnienia z użyciem nowego aparatu analitycznego. Przede wszystkim mam tu na myśli procesy właściwe społeczeństwom późnej nowoczesności, które wydają się kiełkować na obszarach wiejskich. Jednym z takich zjawisk są, jak sądzę, formujące się nowe ruchy społeczne, wprawdzie właściwe dla przestrzeni miejskiej, i tam

2 Pojęcia wsi i obszaru wiejskiego posługują się różnymi perspektywami rzeczywistości społecznej wsi. Można powiedzieć, że w pewnym sensie pokazują one drogę, jaką przeszła, najpierw tworząc względnie zamkniętą wspólnotę o określonym typie dominującej aktywności, jaką jest praca na roli, z charakterystycznym typem więzi społecznej, stosunków krewniaczo-sąsiedzkich i z trwałym współzamieszkiwaniem. Natomiast współcześnie wiele z tych cech nie jest już adekwatnych do jej opisu, dlatego badacze posługują się pojęciem obszaru wiejskiego, które opisuje inną całość, posiadającą odmienny, lub co najmniej zmodyfikowany w porównaniu z wsią, zestaw cech, wśród których najistotniejszą jest stosunkowo niewielka gęstość zaludnienia, bardziej zróżnicowana struktura zawodowa mieszkańców tych obszarów, ograniczona rola rolnictwa czy też rozpad więzi wspólnotowych. Za tymi pojęciami stoi zatem bogaty dorobek analityczny mieszczący się w ramach socjologii wsi i współcześnie socjologii obszarów wiejskich, który pokazuje w rozmaity sposób ewolucję tego układu społeczno-kulturowego od wsi do obszarów wiejskich właśnie. Mając świadomość różnic pomiędzy tradycyjnie pojmowaną wsią i obszarami wiejskimi, chciałbym w tym miejscu zwrócić uwagę czytelnika na fakt, że o ile nie jest to wyraźnie zaznaczone, posługuję się w odniesieniu do współczesności pojęciami wsi i obszaru wiejskiego zamiennie, mając jednak świadomość istnienia różnych desygnatów tych pojęć. 
poszukiwane przez badaczy, ale znajdujące również szczególnie dogodne miejsce do rozwoju na obszarach wiejskich. Potencjał tych obszarów w kontekście powstawania nowych ruchów społecznych dostrzega między innymi Patrick Mooney [2000]. Autor ten stwierdza, że ruchy społeczne stanowią przejaw walki części mieszkańców wsi o zachowanie tożsamości. Ich tożsamość jest bowiem bardziej zakorzeniona w lokalnej, czy regionalnej, przestrzeni niż uniwersalna tożsamość mieszkańców miast. Innymi słowy, mieszkańcy wsi mają więcej powodów do obrony własnej tożsamości niż społeczeństwo miejskie. Ponadto, jak mówi Alberto Melucci, ruchy społeczne należy traktować jako zwiastun czy zapowiedź przyszłości [1996: 1]. Ich obecność na obszarach wiejskich można potraktować jako swego rodzaju wskaźnik późnej nowoczesności, która dociera na te obszary. Są zatem powody, aby zainteresować się wykorzystaniem teorii nowych ruchów społecznych do analiz zachowań, przynajmniej części współczesnych mieszkańców wsi. „Ruchy społeczne są mediami, które mówią poprzez działanie. Nie chodzi o to, że używają słów, sloganów, czy że wysyłają jakieś wiadomości, ale ich funkcja mediatora pomiędzy dylematami systemu i codziennym życiem ludzkim jest wyrażana przede wszystkim poprzez to co robią" [Melucci 1994: 126].

Reasumując, celem tego artykułu nie jest systematyczna analiza procesów modernizacyjnych obecnych na współczesnych obszarach wiejskich w Polsce. Te są przedmiotem pogłębionych analiz i wyjaśnień ze strony wielu badaczy, co znalazło wyraz w licznych opracowaniach z zakresu socjologii obszarów wiejskich i ekonomii. Chodzi raczej o to, aby bez szczegółowych analiz wskazać zjawiska obecne na tych obszarach w Polsce, i nie tylko, które tworzą dogodne podłoże dla formowania się nowych ruchów społecznych. Tym samym, aby wykazać, że to, co zostało już niejednokrotnie opisane, może znaleźć nowy kontekst teoretyczny w postaci teorii ruchów społecznych. Nie jest też moim zadaniem udowadnianie, że na obszarach wiejskich funkcjonuje nowy ruch społeczny pod postacią ruchu agroturystycznego. To zadanie przekraczałoby rozmiary tego artykułu i już wcześniej znalazło rozwiązanie 3 .

Logika wywodu tego artykułu będzie podyktowana chęcią prezentacji w pierwszej kolejności kwestii związanych z ogólniejszymi kontekstami funkcjonowania obszarów wiejskich, następnie przybliżenia procesów, które sprzyjają wyłanianiu się nowych ruchów społecznych na tych obszarach, by w dalszej kolejności zaprezentować ruch agroturystyczny jako przykład takiego właśnie podmiotu powstałego dzięki tym procesom.

3 Szczegółowe charakterystyki ruchu agroturystycznego można znaleźć w: [Foryś 2016]. 


\section{NOWOCZESNOŚĆ I PÓŹNA NOWOCZESNOŚĆ NA OBSZARACH WIEJSKICH. ROLNICTWO JAKO DOMINUJĄCY CZYNNIK MODERNIZACYJNY NA OBSZARACH WIEJSKICH}

Przemiany współczesnego rolnictwa zostały nazwane przez Krzysztofa Gorlacha mianem ,przełomu modernizacyjnego” oraz „postmodernizacyjnego" [Gorlach 2004: 50-51]. Można powiedzieć, że ten pierwszy dokonywał się w społeczeństwie nowoczesnym, natomiast ten drugi przynależy do fazy społeczeństwa późnej nowoczesności. Trudno oczywiście przedstawić w tym miejscu w sposób zadowalający, czyli szczegółowy i wieloaspektowy, wszystkie procesy właściwe każdemu z przełomów, można jednak pokusić się o wyróżnienie kilku dominant charakterystycznych dla każdego z nich.

W ramach okresu modernizacyjnego możemy wskazać dwie kluczowe dominanty, czyli technicyzację i industrializację. Jedną z konsekwencji tego pierwszego procesu była migracja zbędnej na wsi siły roboczej do miast. Natomiast industrializacja, której składnikami są również technicyzacja oraz chemizacja i standaryzacja pracy, wytworzyła silne relacje pomiędzy rolnictwem $i$ jego otoczeniem ekonomicznym, co w konsekwencji doprowadziło do istotnych zmian w obrębie kategorii ludności zajmującej się uprawą ziemi. Towarzyszyły temu zmiany w obrębie świadomości członków tej kategorii społecznej polegające na słabnięciu roli wartości przynależnych do etosu chłopskiego, aż do ich zaniku. Uruchomiony został proces zastępowania kategorii chłopów przez kategorię społeczno-zawodową rolników, producentów rolnych. Zbudowany został samonapędzający się mechanizm, którego podstawą była rynkowa konkurencja, innowacyjność i racjonalność gospodarowania, a skutkiem rosnąca powierzchnia gospodarstw, koncentracja ziemi uprawnej i masowy produkt.

Z kolei w fazie postindustrialnej, która pokrywa się mniej więcej z nastaniem społeczeństwa późnej nowoczesności, rolnictwo poczyniło krok naprzód, co przejawiało i przejawia się między innymi rewolucją biotechnologiczną oraz informatyzacją procesu produkcji rolnej. Celem tych zmian jest oczywiście zwiększanie kontroli nad procesem produkcyjnym oraz poprawienie wydajności produkcji. Nie mniej ważne zmiany zaszły w sferze świadomości konsumentów produktów rolnych i żywnościowych, którzy zwiększyli swoje zainteresowanie dobrym jakościowo, najczęściej ekologicznym produktem. Miało to istotne konsekwencje, ponieważ stworzyło nowe możliwości dla rolnictwa opartego na bardziej tradycyjnych sposobach produkcji, ulokowanego poza rolnictwem wielkoprzemysłowym i z dala od globalnych łańcuchów zaopatrzeniowych. Do tych zmian w fazie postindustrialnej dodać należy również przenikanie na obszary 
wiejskie ogólnospołecznej tendencji polegającej na przesunięciu zainteresowania ze sfery produkcji w stronę konsumpcji. Zwróciło to uwagę społeczną na styl i jakość życia, tworząc jednocześnie nowy punkt odniesienia dla produkcji rolnej oraz obszarów wiejskich. Nastąpiło również zerwanie związków pomiędzy obszarami wiejskimi i produkcją rolną. Wszystkie te procesy sprzyjały i sprzyjają rozwojowi funkcji konsumpcyjnych obszarów wiejskich.

Na podstawie tych charakterystyk można również stwierdzić, że wymienione fazy rozwoju rolnictwa, industrialna i postindustrialna, miały właściwe sobie formy zachowań zbiorowych ludności wiejskiej. Dla pierwszej charakterystyczne były działania zbiorowe zorganizowane pod szyldem związków zawodowych, na wzór „starych” ruchów społecznych zabiegających o interesy ekonomiczne, natomiast w drugiej, współczesnej, coraz wyraźniej widoczne jest tworzenie się bazy pod działalność nowych ruchów społecznych zorientowanych na realizacje wartości postmaterialistycznych.

Można powiedzieć, że opisane tu procesy w rolnictwie szły w parze z ogólniejszymi tendencjami charakteryzującymi społeczeństwo późnej nowoczesności. To znaczy, nawiązując do jej zasadniczych cech nakreślonych przez Jana Pakulskiego [Pakulski 2009], z hiperracjonalizacja, hiperutowarowieniem, hiperdyferencjacją i hiperindywidualizacją. W kontekście obszarów wiejskich szczególnego znaczenia nabiera hiperutowarowienie, polegające, najogólniej rzecz ujmując, na nadawaniu wartości wymiennej dobrom niematerialnym, a w konsekwencji ich sprzedaży na rynku ekonomicznym. Ta ogólnospołeczna tendencja powoduje, że obszary wiejskie, dzięki swym walorom, stają się dogodnym miejscem realizacji wartości postmaterialistycznych. Ich zasoby przyrodnicze i krajobrazowe stwarzają korzystne warunki do aktywnego wypoczynku, produkcji żywności ekologicznej, kontaktu z kulturą ludową i wiejską tradycją, a więc stanowią atrakcyjną ofertę dla zwolenników określonego stylu życia. W ten sposób przenikają na wieś wartości i postawy, które pierwotnie były typowe dla miasta.

Po tej ogólnej prezentacji bliżej przyjrzę się tym procesom, które zostały uruchomione $\mathrm{w}$ rolnictwie późnonowoczesnym wskutek naszkicowanych tu tendencji. Podstawą tych rozważań będzie koncepcja Jana van der Ploega [2008], w której wyraża on swój pogląd na zmiany zachodzące we współczesnym rolnictwie, a które wiążą się bezpośrednio z procesem formowania się nowych ruchów społecznych na obszarach wiejskich. 


\section{PROCESY DETERMINUJĄCE WYLANIANIE SIĘ NOWYCH RUCHÓW SPOŁECZNYCH NA OBSZARACH WIEJSKICH}

Postaram się przedstawić w sposób możliwie zwięzły, ale jednocześnie zrozumiały, główne wątki koncepcji van der Ploega ukazujące wzajemne związki pomiędzy zmianami w rolnictwie i procesami sprzyjającymi wyłanianiu się nowych ruchów społecznych na obszarach wiejskich. Zdaniem autora współczesne światowe rolnictwo funkcjonuje pod trzema postaciami: rolnictwa chłopskiego, opartego na kapitale ekologicznym, którego zasadniczym celem jest zaspokajanie podstawowych potrzeb członków gospodarstwa; rolnictwa uprawianego w ramach przedsiębiorstw rolnych, zorientowanych na rynek, które jest ufundowane na kapitale finansowym; oraz rolnictwa korporacyjnego o zasięgu globalnym, mobilnego i korzystającego wyłącznie z pracy najemnej. Te trzy typy rolnictwa koncentrują się w dwa szersze układy funkcjonujące według odmiennych zasad. Pierwszy układ działa na zasadach zdecentralizowanej produkcji i konsumpcji żywności, istnieją w nim silne związki pomiędzy rolnictwem a społecznościami lokalnymi. Drugi model, w przeciwieństwie do pierwszego, jest scentralizowany, funkcjonują w nim wyspecjalizowane przedsiębiorstwa rolne działające na skalę światową. Współtworzą one tak zwane Imperium (Empire), w skład którego wchodzą również technologie produkcji, wiedza naukowa, instytucje i infrastruktura związane z rolnictwem i dystrybucją żywności. Imperium pozostaje w pozycji dominacji względem pierwszego układu.

Najistotniejsza jest jednak wewnętrzna dynamika światowego rolnictwa, a dokładniej to, jakie zjawiska zachodzą w nim pod wpływem industrializacji. $\mathrm{Z}$ punktu widzenia postawionego w tym artykule pytania kluczowe wydają się być dwa procesy przez nią powodowane, to jest powrót do chłopskości oraz deaktywacja. Industrializacja wywiera silną presję na systemy produkcji rolnej na poziomie lokalnym i regionalnym, prowadząc do marginalizacji części przedsiębiorstw rolnych. Dyktat niskich cen wprowadzony przez Imperium pociaga za sobą niemożność sprostania konkurencji rynkowej i powoduje, jak nazywa to van der Ploeg, schłopienie (repeasantatization) właścicieli upadających gospodarstw. W gruncie rzeczy zjawisko to prowadzi do degradacji ekonomicznej tych ludzi, ale z drugiej strony pozwala im uzyskać niezależność od rynku i w konsekwencji poszerza zakres ich autonomii. Kluczową rolę w generowaniu takich skutków odgrywa industrializacja, ale przyczyny bezpośrednie bywają często bardziej przyziemne. Wypchnięcie z rynku może być równie dobrze spowodowane spadkiem cen, niemożnością spłaty kredytu, jak i nieudanymi inwestycjami. 
Drugi z procesów określany jest przez van der Ploega mianem deaktywacji. Najogólniej rzecz biorąc, u podłoża deaktywacji leżą te same przyczyny co w przypadku opisanego wcześniej procesu schłopienia, jednak warto dodać, że deaktywacja może być również uruchomiona przez decyzje o charakterze instytucjonalnym, czego przykładem są kwoty produkcyjne narzucane przez Unię Europejską, mogące ograniczać produkcję rolną na danym obszarze i eliminować część producentów rolnych. W takich przypadkach podejmowane przez nich działania oznaczają najczęściej przebranżowienie. Zaprzestają oni działalności produkcyjnej, spieniężają swoje gospodarstwo i podejmują aktywności w innych sektorach gospodarki. Nie zawsze oznacza to, że rezygnują z pracy na obszarach wiejskich, ponieważ mogą na przykład funkcjonować na rynku producentów „zielonej” energii czy w ramach turystyki wiejskiej lub agroturystyki. Wspólnym mianownikiem schłopienia i deaktywacji jest obecność w ich tle industrializacji, a także zjawisko osłabiania się więzi pomiędzy właścicielami gospodarstw rolnych a rynkiem ekonomicznym.

Skutki opisanych procesów są wielorakie, od odbudowywania na obszarach wiejskich bardziej tradycyjnego modelu rolnictwa zorientowanego na rynek lokalny i regionalny, przez dywersyfikację produkcji rolnej, jej pogłębianie (np. podnoszenie jakości produktów poprzez produkcję ekologiczna), podejmowanie aktywności pozarolniczej, pozaprodukcyjnej, aż po odradzanie się tradycyjnych form aktywności, na przykład w postaci rzemiosła. Wszystko to stanowi niezamierzone konsekwencje industrializacji w fazie rolnictwa późnonowoczesnego.

Wspomniane zjawiska uboczne powstałe wskutek przeobrażeń rolnictwa postnowoczesnego mogły nabrać pozytywnego charakteru dzięki zaistnieniu sprzyjających ku temu okoliczności. Mam tu na myśli: po pierwsze, oddziaływanie industrializacji, w następstwie której obszary wiejskie stały się w okresie nowoczesności i późnej nowoczesności terenem kolonizacji - chodzi przede wszystkim o jej społeczne i kulturowe skutki dla obszarów wiejskich; po drugie, pomimo destrukcyjnego wpływu industrializacji na tradycyjne rolnictwo nie zniszczyła ona wśród właścicieli gospodarstw rolnych elementów chłopskości, w każdym razie niecałkowicie. Głęboko zakorzenione w świadomości rolników przekonanie o znaczeniu ziemi i pracy na niej pozwoliło im na nowo podjąć wyzwanie w zmienionych warunkach, które stwarzają im nowe możliwości rozwoju. Podzielane wspólnie z innymi mieszkańcami wsi wartości stały się podstawą do budowania sieci lokalnej kooperacji; po trzecie, pozytywnym zjawiskiem było zapotrzebowanie konsumentów na produkt o odpowiedniej jakości, który jest rozpoznawalny dzięki lokalnemu zakorzenieniu, a którego nie jest w stanie zapewnić Imperium; po czwarte, nastapiło swoiste spotkanie wsi i miasta, które 
niejako wspólnie sprzymierzyły się w walce o obronę bardziej tradycyjnych form gospodarowania zorientowanych na odpowiedniąjakość i niepowtarzalność produktów. Organizacje pozarządowe czy nowe ruchy społeczne walczące w obronie tych wartości są tego egzemplifikacją; po piąte, bliskość wsi i miasta przejawia się również w tym, że nie stanowią one swego przeciwieństwa, w takim sensie jak opisywały to klasyczne teorie. Wiejskość zyskuje w oczach mieszkańców miast nową jakość, staje się obszarem, na którym w sposób pełniejszy niż w mieście mogą być realizowane wartości postmaterialistyczne, chociaż to głównie miasta są miejscem egzystencji tych wartości, zakorzenionych w świadomości ich mieszkańców. Mam tu na myśli między innymi styl życia zorientowany na ekologię, zdrową żywność, aktywny wypoczynek lub kontakt z naturą.

Zarysowane tu procesy spowodowały, że na obszarach wiejskich zaistniały dogodne warunki dla formowania się nowych ruchów społecznych. Niemniej jednak wydaje się, że stwarzają one tylko jedną z opcji wyboru, przed jakim stają potencjalni uczestnicy nowych ruchów społecznych na obszarach wiejskich. W tym miejscu należy bowiem wziąć pod uwagę dwie kolejne kwestie, które mają jak sądzę, dosyć istotne znaczenie dla kształtowania się zachowań zbiorowych na wsi. Pierwsza z nich to polityka państwa polskiego oraz Unii Europejskiej wobec obszarów wiejskich. $Z$ jednej strony sprzyja ona rozwojowi rolnictwa wielkoobszarowego, zindustrializowanego, co w konsekwencji eliminuje z rynku mniejsze gospodarstwa, które nie są w stanie sprostać rynkowej konkurencji. W ten sposób polityka ta staje się dodatkowym elementem presji wywieranej na właścicieli gospodarstw z trudem utrzymujących się z produkcji rolnej. Innymi słowy oprócz Imperium, używając określeń van der Ploega, także polityka państwa może stwarzać warunki do schłopienia i deaktywacji. $\mathrm{Z}$ drugiej jednak strony $\mathrm{w}$ ramach polityki wobec obszarów wiejskich państwo i UE kładą nacisk na wielofunkcyjny rozwój tak obszarów wiejskich, jak i samego rolnictwa. Te działania z kolei stwarzają szansę dla tych, którzy chcą się angażować $\mathrm{w}$ działalność pozarolniczą, która może stać się w przyszłości powodem uczestnictwa w nowych ruchach społecznych (np. agroturystyka, produkcja żywności ekologicznej, rzemiosło, produkcja „zielonej” energii). Co więcej, poprzez tego rodzaju działania państwo może stać się podmiotem, który w niezamierzony sposób wspiera powstawanie nowych ruchów społecznych. Jest to szczególnie widoczne wtedy, kiedy organizacje funkcjonujące na obszarach wiejskich (szczególnie stowarzyszenia agroturystyczne, kulturalne, lokalne grupy działania) aplikują o środki finansowe w ramach rozmaitych programów. Fakt ten staje się podstawą do kooperacji między nimi, jak również do szerszego kultywowania ważnych dla nich wartości związanych z ekologią, zdrowym stylem 
życia, wiejskością, krajobrazem i wiejską kulturą. Innymi słowy, państwo wraz z jego polityką wobec obszarów wiejskich, która jest istotnie stymulowana przez UE, w dwojaki sposób przyczynia się do tworzenia sprzyjających warunków dla powstawania nowych ruchów społecznych na tychże obszarach, to znaczy tworzy w niezamierzony sposób bazę społeczną dla tych ruchów, jak również wspiera je finansowo.

Druga kwestia, o której należy powiedzieć, to zaangażowanie w zachowania zbiorowe właścicieli gospodarstw rolnych. Zarysowana tu ścieżka jest jedną z możliwych i dotyczy głównie tych, którzy wycofują swoje gospodarstwa z ryn$\mathrm{ku}$, ewentualnie podejmują inną działalność obok produkcji rolnej. W tej grupie właścicieli należałoby poszukiwać potencjalnych uczestników nowych ruchów społecznych i traktować je jako formę obrony przed opresją systemu. Nie należy jednak zapominać, że oprócz nich znajdą się też tacy, którzy skłonni są do obrony własnej pozycji w bardziej zdecydowany sposób, poprzez angażowanie się w protesty społeczne lub związki zawodowe, a więc w działania charakterystyczne bardziej dla „starych” ruchów społecznych. Zatem ich aktywność również można analizować, posługując się teoriami ruchów społecznych, co zresztą ma potwierdzenie w badaniach polskich i międzynarodowych. Można zatem powiedzieć, że charakteryzowane $\mathrm{w}$ tym artykule warunki sprzyjające powstawaniu nowych ruchów społecznych na obszarach wiejskich nie sąjedynym przypadkiem, kiedy te teorie mają zastosowanie do analiz aktywności zbiorowej mieszkańców wsi.

\section{NOWE RUCHY SPOLECZNE NA OBSZARACH WIEJSKICH. PRZYCZYNEK DO DYSKUSJI}

Gdzie w takim razie możemy znaleźć przesłanki dla formowania się nowych ruchów społecznych na obszarach wiejskich? Wydaje się, że należy ich szukać właśnie w bliższych i dalszych kontekstach funkcjonowania tych obszarów. Do dalszych uwarunkowań zaliczyć należy przede wszystkim przejście społeczeństw od orientacji materialistycznej do postmaterialistycznej, o czym pisali między innymi Ronald Inglehart i, w kontekście ruchów społecznych, Claus Offe. Niemniej jednak w fazie początkowej dotyczyło to głównie społeczności miejskich, a nie wiejskich. Aby ten trend dotarł na obszary wiejskie, konieczne były ich daleko idące zmiany, które zbliżyły je do obszarów miejskich. Procesem, który spełnił tę rolę, w sposób niezamierzony, była właśnie industrializacja. Przede wszystkim jednak industrializacja stworzyła owo Imperium, które w największym stopniu determinuje współczesne rolnictwo. Generowane przez nie procesy schłopienia i deaktywacji otworzyły drzwi do powrotu bardziej tradycyjnych form 
gospodarowania. Wytworzyły zarówno grupę mniejszych gospodarstw rolnych, zorientowanych na rynek lokalny i regionalny oraz pozwoliły znacznemu gronu mieszkańców obszarów wiejskich pozytywnie odpowiedzieć na płynące z miast zapotrzebowanie na zasoby posiadane przez wieś. Mam tutaj na myśli potrzeby związane ze wspomnianym już określonym stylem życia, które właśnie wieś może zaspokoić.

Więcej informacji o procesach budowania podłoża dla nowych ruchów społecznych dostarczają nam bliższe konteksty obszarów wiejskich. Kluczowe są tu procesy związane z produkcją rolną, która zdaniem van der Ploega stanowi miejsce walki o autonomię prowadzoną przez producentów rolnych z Imperium. Zasadniczym czynnikiem determinującym procesy produkcji wydaje się być rynek ekonomiczny, pozostający pod kontrolą zindustrializowanego sektora rolnego oraz związany z nim przemysł żywnościowy. Głównymi uczestnikami tej walki są tak zwani „nowi” chłopi, czyli ci, którzy wyłaniają się wskutek procesów schłopienia. Nie walczą o swoje interesy, organizując protesty, rebelie czy wojny chłopskie, ale współtworząc model rolnictwa, który staje się konkurencyjny wobec wszechobecnego Imperium. Nauka, państwo i instytucje zajmujące się rolnictwem tworzą również ramy organizacyjno-instytucjonalne dla tego rodzaju działań, pod postacią postproduktywistycznego czy też zrównoważonego modelu rolnictwa [Marsden 2003]. Pierwszy z nich sprzyja głównie rozwojowi pozarolniczych funkcji obszarów wiejskich, drugi koncentruje się na wielofunkcyjnym rozwoju obszarów wiejskich. Wydaje się, że właśnie model zrównoważony, który znajduje dogodny grunt do realizacji na tych obszarach, gdzie nie odcisnął swojego piętna model przemysłowy, uosabiany przez Imperium, stwarza dobre środowisko dla rozwoju nowych ruchów społecznych. Jego realizacja nie jest wynikiem odgórnej polityki, w każdym razie nie tylko, ale wynika z codziennej praktyki działania części mieszkańców wsi. A ta pokazuje, że rolnictwo w ramach tego modelu jest zakorzenione lokalnie, bezpośrednio związane z konsumentami i dostosowane do lokalnego kontekstu kulturowego. Co ważniejsze jednak, model ten nie jest jedynie rezultatem kryzysu rolnictwa przemysłowego, ale przede wszystkim zapotrzebowania społecznego na wartości postmaterialistyczne, np. ekologiczną żywność czy zdrowy, aktywny styl życia w kontakcie z naturą.

Na podstawie dotychczasowych ustaleń można sformułować wniosek, że trendy obecne we współczesnym rolnictwie i szerszym społeczeństwie wytworzyły korzystne warunki dla wyłaniania się na obszarach wiejskich nowych ruchów społecznych. Obszary te stają się coraz częściej także obiektem zainteresowania ze strony ruchów przychodzących z zewnątrz (np. ruchu ekologicznego, ruchów 
zorganizowanych wokół zdrowej żywności, czy szerzej - kultywujących zdrowy styl życia w symbiozie z natura), lub wręcz na tych obszarach rodzą się nowe ruchy społeczne (np. ruch agroturystyczny, ruchy pielęgnujące tradycyjną kulturę wiejską). Zatem teorie ruchów społecznych, zwłaszcza nowych ruchów społecznych, mogą stanowić przydatne narzędzie analityczne dla niektórych procesów zachodzących współcześnie na obszarach wiejskich.

W tym miejscu konieczne wydaje się przybliżenie istoty teorii nowych ruchów społecznych, w takim stopniu, który pozwala powiązać omawianą do tej pory problematykę z kwestią ruchów społecznych.

Teorie nowych ruchów społecznych są dominującym podejściem teoretycznym przede wszystkim w krajach zachodnioeuropejskich (w przeciwieństwie do Stanów Zjednoczonych, gdzie dominuje teoria mobilizacji zasobów) [Klandermans, Tarrow 2008]. Do głównych teoretyków tego nurtu należą Alain Touraine, Manuel Castells, Alberto Melucci i Jürgen Habermas [Buechler 2008], chociaż powszechnie używane określenie „,nowe ruchy społeczne” zawdzięczamy głównie Clausowi Offe [1995], który trafnie uchwycił zachodzące w XX wieku zmiany w kontekstach funkcjonowania ruchów społecznych.

Wśród badaczy nowych ruchów społecznych istnieją spory co do tego, jaki zbiór cech wyróżnia te podmioty. Najistotniejsze różnice zdań dotyczą następujących kwestii: co nowego jest w nowych ruchach społecznych, czy mają one progresywny czy regresywny charakter, czy posiadają naturę polityczną czy też kulturową oraz jakie jest ich zaplecze klasowe. Nie ma tu miejsca na szczegółowe rozpatrzenie tych dylematów, warto jednak powiedzieć, że interesującego podsumowania dyskusji dokonał Steven Buechler [2008]. Ponadto należy wskazać, że spośród wszystkich toczonych sporów wokół przywołanych tu kwestii zasadnicze znaczenie dla zrozumienia istoty nowych ruchów społecznych mają debaty na temat tego, co świadczy o nowości tych ruchów. Moim zdaniem w największym stopniu świadczą o tym cele realizowane przez te podmioty. Jak mówi Offe, wraz ze zmianą otoczenia ruchów społecznych zmianie uległy również ich cele, przechodząc transformację od celów materialistycznych do postmaterialistycznych. One też, jak sądzę, w największym stopniu odzwierciedlają w sferze ruchów społecznych to, co zaszło w społeczeństwach w czasie przejścia od wczesnej do późnej fazy modernizacji.

Jak się okazuje, teoria nowych ruchów społecznych posiada walory poznawcze nie tylko w odniesieniu do ruchów funkcjonujących w mieście, jak widzi to między innymi Castells, ale również ruchów na współczesnych obszarach wiejskich. Po pierwsze, wydaje się użyteczna zwłaszcza w kontekście obrony 
zbiorowej tożsamości, co w przypadku mieszkańców wsi nabiera szczególnego znaczenia. Procesy modernizacyjne, które zachwiały wspólnotami lokalnymi, osłabiły więzi społeczne, zwiększyły poziom atomizacji i indywidualizacji, napotykają opór tych społeczności. Wyraża się to między innymi podkreślaniem przez mieszkańców wsi posiadanych lokalnych zasobów, budowaniem własnej tożsamości w oparciu o lokalność czy kultywowaniem wiejskiej tradycji. Po drugie, na obszarach wiejskich silniejsza jest relacja pomiędzy mieszkańcami i władzą lokalną. Nowe ruchy społeczne przywiązują do tego typu relacji, która zwiększa obywatelską partycypację, dużą wagę. Ta bliskość daje poczucie większego wpływu na władzę. W kontekście dysponowania środkami europejskimi, a co za tym idzie, możliwościami aplikowania o nie przez rozmaite lokalne podmioty, istnieje szerokie pole wzajemnej współpracy pomiędzy władzą a mieszkańcami. Po trzecie, i najważniejsze, jak sądzę, wieś jest poddawana coraz silniejszym wpływom procesów modernizacyjnych, które niszczą tradycyjne wartości, wspólnotę czy kulturę wiejską. Reakcją na te procesy jest formowanie się ruchów, które mają na celu obronę tradycyjnych elementów wiejskości. Po czwarte, wieś jest obszarem, na którym mogą być realizowane rozmaite wartości postmaterialistyczne, zwłaszcza te odnoszące się do przyrody. Coraz wyraźniej obecna w szerszym społeczeństwie orientacja postmaterialistyczna zyskuje w obszarach wiejskich poważnego sojusznika. Kontakt z natura, krajobraz, zdrowa żywność, tradycja to zasoby, które czynią wieś atrakcyjną w kontekście wspomnianej tu tendencji.

Perspektywa nowych ruchów społecznych wydaje się pełniej wyjaśniać procesy zachodzące na obszarach wiejskich, między innymi dlatego, że opisywane przez nią ruchy są zorientowane przede wszystkim na akcentowanie zbiorowej tożsamości, realizację wartości postmaterialistycznych, akcentowanie roli władzy lokalnej czy obronę wartości. Przywołana wcześniej walka rolników z Imperium jest przykładem bitwy o zachowanie zbiorowej tożsamości i więzi społecznych wynikających z danego, konkretnego miejsca. Ta wiejska tożsamość jest zakorzeniona w lokalnej historii, tradycji i strukturze społecznej. Rezygnacja z nich, brak obrony przez ruchy społeczne powoduje, że wieś staje się bezbronna i podatna na wpływy zewnętrzne - jak mówi Mooney [2000: 50]. Funkcjonujący na obszarach wiejskich ruch agroturystyczny byłby z kolei przejawem realizacji wartości postmaterialistycznych, podobnie jak ruchy zorganizowane wokół obrony tradycji i kultury wiejskiej. Mooney zauważa, że wiejskie nowe ruchy społeczne są jednak nieco inne niż te w miastach [2000: 51]. Jest to spowodowane tym, że te pierwsze zaabsorbowane są codziennością, która jest jednak inna niż 
codzienność miejska. O ile na wsi walka toczy się o zachowanie tego, co jest, o tyle w mieście dotyczy tego, co zostało utracone.

Obszary wiejskie są miejscem gdzie walka przeciwko kolonizacji życia społecznego, jak powiedziałby Habermas, jest wyraźniej zauważalna. Ich opresja staje się współcześnie bardziej widoczna, a wpływy z zewnątrz są natychmiast wychwytywane przez mieszkańców wsi. Ujmując rzecz jeszcze inaczej, w stylu Touraine'a, na wsi widoczna jest również wyraźniej walka o kontrolę nad dominującymi w społeczeństwie wzorcami kulturowymi. Co więcej, wieś nie jest w tej walce skazana na porażkę, co wydaje się być powodowane trzema faktami. Po pierwsze, elementy wiejskości związane ze stylem życia i zbiorem wartości obecnym wyraźniej na wsi niż w mieście (zdrowy styl życia, ekologia, zdrowa żywność, aktywność fizyczna) stały się częścią ważnej orientacji ogólnospołecznej. Po drugie, wieś ma w stosunku do miasta „przewagę” zacofania, która powoduje, że to, o co walczy wiele miejskich ruchów społecznych, nie zostało jeszcze na wsi utracone. Po trzecie, wieś zyskuje nowych sprzymierzeńców rekrutujących się z obszarów miejskich, którzy zawodowo umocowani są właśnie w mieście, ale to obszary wiejskie stały się dla nich miejscem realizacji wartości postmaterialistycznych związanych z marzeniem o lepszym życiu. Innymi słowy, wiejskie nowe ruchy społeczne zyskują coraz liczniejszą bazę zakorzenioną w strukturze społecznej.

\section{RUCH AGROTURYSTYCZNY W POLSCE. EGZEMPLIFIKACJE EMPIRYCZNE}

W tej części artykułu chciałbym poczynić wstępne uwagi na temat ruchu agroturystycznego uformowanego w Polsce na obszarach wiejskich. Na jego przykładzie wyartykułuję te cechy, które moim zdaniem w największym stopniu świadczą o tym, że można go potraktować jako nowy ruch społeczny. Będą to, zgodnie z sugestiami Clausa Offego [1995], cele ruchu, jego uczestnicy i sposoby działania. Pomijam tu dyskusję, która toczy się wśród badaczy ruchów społecznych na temat tego, czy w ogóle możemy mówić o swego rodzaju nowości charakteryzującej współcześnie tak zwane nowe ruchy społeczne. Jak już powiedziałem, warto $\mathrm{w}$ tej kwestii zapoznać się z relacją dotyczącą tego sporu przedstawioną przez Stevena M. Buechlera [2008]. Przedstawione w tym miejscu charakterystyki są pokłosiem badań empirycznych zrealizowanych techniką wywiadu pogłębionego wśród celowo dobranych właścicieli 20 gospodarstw agroturystycznych usytuowanych w Małopolsce oraz 35 organizacji agroturystycznych działających na terenie Polski. Zasadniczo celem badań było przetestowanie hipotezy na temat istnienia ruchu agroturystycznego, a w przypadku jej weryfikacji opisanie 
i wyjaśnienie roli, jaką pełni on na obszarach wiejskich. Systematyczna analiza jego cech, uwzgledniających między innymi stosunek do zmiany społecznej, interakcyjność oraz wspólnotę celów i opinii, samoświadomość i ocenę poczucia przynależności do ruchu pozwoliły na potwierdzenie postawionej hipotezy. Jak widzimy, zakres cech będących przedmiotem analizy jest szerszy od tego prezentowanego poniżej. W tym miejscu chodzi raczej o uwypuklenie tego, co świadczy o „nowości” ruchu, a nie o jego pełną charakterystykę.

Sądzę, że o wyjątkowości nowych ruchów społecznych w największym stopniu świadczą ich cele. Najogólniej rzecz biorąc, cele te koncentrują się wokół świata i życia. Kryją się za nimi bardzo konkretne kwestie materialne i niematerialne, takie jak: prawo jednostki do kształtowania własnej tożsamości, ochrona środowiska, tolerancja, sprawiedliwość społeczna, pacyfizm, rozwój zrównoważony, prawa człowieka, zdrowy styl życia, by wymienić tylko niektóre z celów, jakie stawiają przed sobą nowe ruchy społeczne. Jednocześnie odrzucają one wzrost ekonomiczny za wszelką cenę, kulturę masową, konsumpcjonizm, komercjalizację i autorytaryzm, tym samym sprzeciwiają się oficjalnej aksjologii związanej z rozwojem cywilizacyjnym. Jakie zatem cele dominują w analizowanym ruchu agroturystycznym? Można je podzielić według dwóch kryteriów. Pierwsze kryterium to hierarchia celów deklarowana przez uczestników ruchu (nadrzędne i podrzędne), drugie - charakter celów (materialistyczne i postmaterialistyczne). Na tej podstawie wyróżniamy cztery typy celów, które zostały przedstawione w Tabeli 1.

TABELA 1. Cele ruchu agroturystycznego

\begin{tabular}{|c|l|l|}
\hline $\begin{array}{c}\text { Charakter celów } \\
\text { Znaczenie celów }\end{array}$ & \multicolumn{1}{|c|}{ Materialistyczne } & \multicolumn{1}{|c|}{ Postmaterialistyczne } \\
\hline \multirow{2}{*}{ Nadrzędne } & $\begin{array}{l}\text { promocja gospodarstwa/wsi/ } \\
\text { regionu, zaspokajanie oczekiwań } \\
\text { i potrzeb agroturystów, pozy- } \\
\text { skiwanie klientów, zyski z agro- } \\
\text { turystyki, działania w interesie } \\
\text { członków, ekologiczna produkcja } \\
\text { rolna }\end{array}$ & $\begin{array}{l}\text { wpływanie na politykę gminy w za- } \\
\text { kresie projektów wspomagających } \\
\text { agroturystykę, ochrona środowiska } \\
\text { i krajobrazu, podtrzymanie istnienia } \\
\text { gospodarstwa rolnego, gratyfikacje } \\
\text { interpersonalne, działania edukacyj- } \\
\text { ne, rozwój społeczności lokalnych } \\
\text { i ich integracja }\end{array}$ \\
\hline Podrzędne & $\begin{array}{l}\text { poprawa standardu usług, do- } \\
\text { kształcanie się, odbywanie szko- } \\
\text { leń, rozwój agroturystyki, współ- } \\
\text { praca z innymi organizacjami }\end{array}$ & $\begin{array}{l}\text { zmiana mentalności/stosunku ludzi } \\
\text { do przyrody, wzajemnej współpracy } \\
\text { w ramach ruchu, rozwój zrówno- } \\
\text { ważony }\end{array}$ \\
\hline
\end{tabular}

Źródło: badania własne. 
Jak wspomniałem, właściwością nowych ruchów społecznych jest propagowanie i realizacja celów postmaterialistycznych, widzimy jednak, że spory udział w ruchu agroturystycznym mają też cele o charakterze materialistycznym, których realizacja - dodajmy dla wyjaśnienia - stanowi właściwie podstawowy wymóg trwania i rozwoju tego ruchu. Działalność agroturystyczna jest bowiem jednym ze źródeł dochodów dla właścicieli tego typu gospodarstw i bez niej gospodarstwa te musiałyby upaść. Mam tu na myśli nie tylko działalność agroturystyczną, ale również związaną z tym uprawę roli i hodowlę zwierząt. Poza tym obecność celów materialistycznych nie wyklucza tych postmaterialistycznych. Można nawet zaryzykować stwierdzenie, że te pierwsze stanowią swego rodzaju narzędzie do realizacji tych drugich. Ilustruje to postawa zarówno właścicieli gospodarstw agroturystycznych, jak i liderów stowarzyszeń. W obu tych grupach obecne są dwie wyraźne tendencje. W gronie kwaterodawców daje się zauważyć ewolucję ich postaw względem roli wartości postmaterialistycznych. W praktyce oznacza to, że w momencie zakładania działalności agroturystycznej jedyną ich motywacją była perspektywa zysku, jednak po pewnym czasie odkrywali znaczenie realizowanych przez siebie wartości, takich jak relacje interpersonalne, podtrzymywanie tradycyjnego obrazu wsi, ekologia, zachowywanie krajobrazu, zdrowy styl życia czy ochrona środowiska. Wartości te z czasem stawały się dla nich pierwszoplanowe, aczkolwiek, jak twierdzili, aby je realizować, gospodarstwo agroturystyczne musi generować dochód. Z kolei w grupie stowarzyszeń, wśród ich liderów, znaczenie celów przedstawia się nieco inaczej w stosunku do tego, co jest prezentowane w oficjalnych dokumentach. Liderzy kładą przede wszystkim nacisk na cele instrumentalne, takie chociażby jak promocja regionu czy wzajemne polecanie sobie gości przez kwaterodawców zrzeszonych w ich ramach, z kolei oficjalne cele mają przede wszystkim charakter postmaterialistyczny i koncentrują się na zachowaniu krajobrazu, ochronie środowiska, podtrzymywaniu wiejskiej kultury i tradycji oraz rozwoju zrównoważonym. W przypadku stowarzyszeń widoczne jest z jednej strony utowarowienie tych wartości, polegające na ich propagowaniu w celu przyciagania potencjalnych gości i promowaniu gospodarstw agroturystycznych, z drugiej strony liderzy tych stowarzyszeń wykazują realne przywiązanie do nich i podkreślają ich rolę we współczesnym społeczeństwie.

Wspólnota celów i opinii jest też podstawą dla formowania się ideologii ruchu agroturystycznego. Jej opis możliwy jest dzięki odwołaniu się do dwóch koncepcji obecności ideologii w ruchu społecznym, pierwszej - Colina J. Becka [2013], który proponuje cztery perspektywy jej ujęcia (psychologiczną, interakcjonistyczna, ramy znaczeniowej oraz strukturalną) oraz drugiej - autorstwa Luthera Gerlacha, który wyróżnia dwa poziomy jej funkcjonowania: wyższy 
i niższy [2001: 301]. Żeby ułatwić zrozumienie koncepcji Becka, dodam, że w perspektywie psychologicznej ideologia służy nadawaniu znaczeń i sensów światu społecznemu przez aktorów, zarówno w wymiarze indywidualnym, jak i zbiorowym. Wykorzystywana jest przez aktorów i grupy społeczne jako podstawa ich identyfikacji. W perspektywie interakcjonistycznej traktuje się ideologię jako zjawisko o charakterze interakcyjnym, ujawniające się w ruchach społecznych w okresach mobilizacji i kształtowane w drodze interakcji pomiędzy liderami i członkami ruchu społecznego, a także pomiędzy ruchem a jego otoczeniem. Zgodnie z kolejną propozycją, którą omawia Beck, nawiązując do koncepcji ramifikacji znaczeń Benforda i Snowa, ideologia jest traktowana jako rama znaczeniowa, która artykułuje, wzmacnia i przekształca istniejące przekonania i wartości we wzorce i cele ruchu społecznego, będąc jednocześnie częścią ogólniejszej kultury. W ostatniej koncepcji ideologii Beck przedstawia ją jako stały czynnik odzwierciedlający się w porządku i strukturze społecznej. Pokazuje w ten sposób proces jej instytucjonalizacji. Z kolei w rozumieniu Gerlacha wyższy poziom ideologii obejmuje poglądy, co do których w ruchu społecznym panuje zgoda; natomiast niższy poziom - taktyki ruchu społecznego oraz mniej znaczące cele związane z tym, co powinno podlegać zmianie.

Koncepcja Becka wydaje się stopniować poziomy, na których występuje ideologia ruchu społecznego, począwszy od poziomu jednostkowego, przez poziom zbiorowości, na strukturze społecznej kończąc. W związku z tym na każdym z nich możemy poszukiwać ideologii ruchu agroturystycznego. Wydaje się jednak, że do jej opisu w ramach przedstawianego tu przypadku właściwe jest rozumienie ideologii zaproponowane powyżej w pierwszym i trzecim znaczeniu. Jest tak, ponieważ aktorzy ruchu (właściciele gospodarstw agroturystycznych i liderzy stowarzyszeń) wydają się być na tyle przywiązani na poziomie indywidualnym do zbioru wartości, które propagują w ramach ruchu, że stanowią one podstawę dla ich samoidentyfikacji. Wypowiedzi tych osób pokazują związek pomiędzy indywidualną tożsamością a działaniem zbiorowym w ramach ruchu społecznego. Ponadto swoiste spotkanie wartości i celów propagowanych przez kwaterodawców z oczekiwaniami i wartościami obecnymi coraz wyraźniej w szerszym społeczeństwie pozwala nam myśleć o ideologii jako o swoistej ramie znaczeniowej zakorzenionej w szerszym społeczeństwie, której depozytariuszem są w większości właściciele gospodarstw agroturystycznych. Jej zawartość tworzona jest zarówno przez przywiązanie do dbałości o przyrodę, krajobraz i tradycję, jak i przez wybrane elementy etosu chłopskiego.

Natomiast ujmując kwestię ideologii w ramy koncepcji Gerlacha, do składników ideologii funkcjonującej na wyższym poziomie ruchu agroturystycznego, 
a więc tych najważniejszych, możemy zaliczyć takie elementy, jak: ochrona środowiska i krajobrazu oraz wiejska kultura i tradycja. $Z$ kolei do poziomu niższego, bardziej zróżnicowanego, zaliczyłbym niektóre składniki etosu chłopskiego oraz szczegółowe cele związane z promocją regionu, turystyki, osiąganiem zysków z prowadzenia gospodarstwa czy kierunkami rozwoju poszczególnych gospodarstw. Reasumując, cele ruchu agroturystycznego z jednej strony maja w znacznym stopniu charakter postmaterialistyczny, z drugiej zaś strony cechuja się pewną swoistością, co jest widoczne w ich odmienności w stosunku do jakości celów propagowanych przez typowe nowe ruchy społeczne. Tę swoistość zawdzięczają przede wszystkim stałej obecności celów materialistycznych, które pełnią rolę narzędzia do realizacji celów postmaterialistycznych.

Charakter uczestników nowych ruchów społecznych jest kolejną cechą wyróżniającą te podmioty. Można powiedzieć, że dominującym rysem, jeśli chodzi o tę kwestię, jest bezklasowość nowych ruchów społecznych w przeciwieństwie do tych starych, które miały właśnie klasowy charakter. Jeśli już chcielibyśmy wskazać na jakieś elementy struktury społecznej powiązane z nowymi ruchami społecznymi, to zgodnie z tym, co mówi Offe, należałoby wymienić emerytów, gospodynie domowe lub studentów, którzy z racji posiadania większej niż inne grupy społeczne ilości czasu wolnego częściej angażują się w tego typu działania zbiorowe. Zasadniczo jednak należy stwierdzić, że uczestnikami nowych ruchów społecznych są głównie przedstawiciele starej i nowej klasy średniej, choć możliwa jest również obecność innych klas i warstw społecznych.

Potwierdzeniem tego stanu rzeczy są ludzie działający w ruchu agroturystycznym. Na pierwszy rzut oka - mając na uwadze, że blisko połowa uczestników wywiadów spośród kwaterodawców (9 na 20) uważa się za rolników, a w badaniach reprezentatywnych przeprowadzonych w 2015 roku wśród małopolskich kwaterodawców przez oddział krakowski Centrum Doradztwa Rolniczego aż $31 \%$ z nich zadeklarowało, że jest rolnikami - można powiedzieć, że mamy do czynienia raczej z warstwowym zakorzenieniem uczestników tego ruchu. Jest to jednak pozorne. Bliższe charakterystyki pokazują bowiem, że najczęściej gospodarują oni na niewielkim obszarowo gospodarstwie, a ich przywiązanie do wartości etosu chłopskiego jest niewielkie. Tylko część z nich - tych, którzy odziedziczyli gospodarstwo, rzeczywiście można nazwać rolnikami, i to bardziej z wyboru niż wykształcenia. Większość z nich nie utożsamia się z zawodem rolnika, nawet jeśli formalnie taki zawód wykonuje lub posiada wykształcenie rolnicze. Z kolei ci, którzy nie wykonują tego zawodu i nie utożsamiają się z nim, prowadząc jednocześnie gospodarstwo agroturystyczne, są umocowani zawodowo poza rolnictwem, wykonując rozmaite zawody, od przyrodnika, przez pracownika 
ubezpieczeń, po nauczyciela akademickiego. Są to zatem zawody wykonywane przez przedstawicieli klasy średniej. Szczególną rolę w ruchu agroturystycznym pełnią osoby napływowe, czyli takie, które przeprowadziły się na wieś w celu prowadzenia gospodarstwa agroturystycznego, a główną motywacją leżącą u podstaw tej decyzji była chęć realizacji wartości postmaterialistycznych związanych z wsią i wiejskością. W ramach badanej próby stanowiły one odrębną kategorię osób. W stosunku do nich możliwe jest stwierdzenie, że stanowią swego rodzaju awangardę tego ruchu, wykazują najsilniejsze przywiązanie do wspomnianych wartości, które przywiodły je na obszary wiejskie.

Swoistość zaplecza społecznego ruchu agroturystycznego potwierdza także wykształcenie jego uczestników. W gronie kwaterodawców spośród 20 przebadanych osób 9 miało wykształcenie wyższe, 5 - średnie i 5 -zawodowe, tylko jedna osoba legitymowała się wykształceniem podstawowym. Jeszcze wyraźniej tendencja ta była widoczna wśród liderów stowarzyszeń - 26 osób spośród 35 miała wykształcenie wyższe, 7 - średnie i tylko po jednej - zawodowe i podstawowe. Świadczy to o stosunkowo wysokim poziomie kapitału ludzkiego w gronie liderów, którzy wraz ze wspomnianymi już osobami napływowymi tworzą swego rodzaju elitę agroturystyki. O wysokiej pozycji świadczą również wykonywane przez nich zawody, wymagające wysokich kwalifikacji. Mamy zatem do czynienia z ludźmi, którzy stanowią grupę liderów w swoim środowisku, zaangażowanych nie tylko w działalność agroturystyczną, ale szerzej - lokalną, która zmierza do twórczego wykorzystania możliwości, jakie dają wieś, rolnictwo, walory przyrodnicze, wiejska tradycja i kultura. Także wspomniane już badania reprezentatywne zrealizowane przez krakowski oddział CDR wśród kwaterodawców pokazały, że poziom wykształcenia jest wyróżniającą cechą uczestników ruchu agroturystycznego; $51,2 \% \mathrm{z}$ nich posiadało wykształcenie średnie, $19,9 \%$ - wyższe, $25,9 \%$ - zawodowe i tylko $2,5 \%$ - podstawowe. Jeśli dodamy do tego fakt, że w zdecydowanej większości prowadzący gospodarstwa agroturystyczne to kobiety (13 na 20 i 73,6\% w badaniach reprezentatywnych zrealizowanych w Małopolsce) oraz to, że swój istotny udział w tym gronie mieli emeryci, to wyłoni nam się obraz bazy społecznej charakterystycznej dla nowych ruchów społecznych. $Z$ jednej strony mamy bowiem kategorie będące niejako poza systemem (emeryci, gospodynie domowe, które stanowiły liczne grono kobiet) z drugiej zaś przedstawicieli klasy średniej, wśród których ważną rolę pełniły osoby napływowe na obszary wiejskie. Reasumując, uczestników ruchu agroturystycznego można podzielić na trzy kategorie,: pierwsza, najmniej liczna, to rolnicy zdradzający przywiązanie do etosu chłopskiego, druga, najliczniejsza, to osoby dystansujące się od zawodu rolnika, najczęściej zaangażowane w dzia- 
łalność zawodową poza rolnictwem i właściwą dla tak zwanej klasy średniej, i trzecia kategoria, stanowiąca awangardę tego ruchu, to osoby napływowe na obszary wiejskie.

Metody działania to kolejny wymieniany przez Offego wymiar, w którym ujawnia się zmiana w stosunku do tego, z czym mieliśmy do czynienia w ramach starych ruchów społecznych. Najogólniej rzecz ujmując, możemy powiedzieć, że charakterystycznym sposobem ich wyrażania się są rozmaite formy protestu. Dominuje wśród nich logika działania instrumentalnego, nastawionego na realizację własnych celów lub celów kategorii społecznych, które reprezentują. Zwykle chcą mieć wpływ na proces decyzyjny lub nawet uczestniczyć w sprawowaniu władzy. Z kolei nowe ruchy społeczne działają przede wszystkim według logiki ekspresyjnej. Dążą do potwierdzenia swojej odrębności i propagowanych przez siebie celów. W sposobie ich działania możemy wyróżnić wymiar wewnętrzny i zewnętrzny. Ten pierwszy manifestuje się w działaniach uczestników ruchu zmierzających do ustanowienia wspólnoty, która decyduje o jego istnieniu jako ruchu właśnie. Powstaje on w sposób dość przypadkowy, niejako ad hoc, przynajmniej w początkowej fazie rozwoju. Podobnie jest w zewnętrznym wymiarze jego funkcjonowania. Niekiedy trudno wyznaczyć granicę pomiędzy nim a jego środowiskiem. Ważniejszy jest tu jednak fakt, że w kontakcie z otoczeniem sięgają po nowatorskie i niekonwencjonalne formy działania, np. happeningi, przemarsze, parady, konferencje czy publikacje propagujące określone wartości i postawy. Często są one kontrkulturową kontestacją dominujących instytucji. Melucci [1988] nazywa to „ukrytym” i ,jawnym” wymiarem działania nowych ruchów społecznych. W pierwszym przypadku kryje się za tym tworzenie nowego, alternatywnego systemu znaczeń, drugi przypadek oznacza konfrontację ruchu $\mathrm{z}$ dominującym modelem kulturowym.

Ruch agroturystyczny w zarysowanej tu perspektywie jawi się jako dosyć specyficzny. Przede wszystkim rzadko podejmuje działania protestacyjne lub sięga po formy wyrazu w postaci happeningów czy parad. Zdecydowanie częściej jego aktywność wyraża się poprzez organizowanie szkoleń, konferencji czy wydawanie publikacji propagujących określone wartości. Te ostatnie są zwykle związane z lokalną kultura, lokalnymi zwyczajami, obrzędami, potrawami czy atrakcyjnymi krajobrazami. Szczególnymi formami działania ruchu agroturystycznego są targi agroturystyki organizowane corocznie, stanowiące zwykle okazję do propagowania wartości związanych z wsią i wiejskością wśród szerokiego grona odbiorców. Oczywiście nie sposób zapomnieć w tym miejscu także o tym, że tego rodzaju spotkania służą szeroko pojmowanej promocji gospodarstw agroturystycznych jako miejsc wypoczynku. Inną formą aktywności ruchu agroturystycznego jest 
uczestnictwo w lokalnych świętach (np. święcie chleba czy festiwalu śliwki). Często to właśnie ten ruch jest inspiratorem tego rodzaju przedsięwzięć. Osobno należy potraktować w tym kontekście jego działalność edukacyjną. Realizuje się ona na poziomie poszczególnych gospodarstw i wynika $z$ edukacyjnej funkcji samej agroturystyki. Ale ta forma aktywności przybiera też postać zinstytucjonalizowaną, co manifestuje się istnieniem ogólnopolskiej sieci zagród edukacyjnych, a także ponad dwustu gospodarstw edukacyjnych na terenie Polski.

Zdecydowanie słabiej reprezentowane są działania o charakterze protestacyjnym; jeśli już do nich dochodzi, to zwykle koncentrują się one wokół spraw lokalnych, związanych między innymi z zagospodarowaniem przestrzeni, ochroną środowiska lub inwestycjami zachowującymi tradycyjny obraz wsi, a ich adresatami są władze samorządowe. Za szczególny rodzaj działalności ruchu agroturystycznego można uznać jego współpracę z otoczeniem, przede wszystkim z innymi podmiotami związanymi z rolnictwem; najczęściej są to: gospodarstwa ekologiczne, twórcy ludowi i stowarzyszenia propagujące kulturę ludową. W ramach tej kooperacji specyficzną rolę pełnią władze samorządowe. Ruch agroturystyczny aktywnie uczestniczy w pozyskiwaniu różnego rodzaju środków finansowych służących rozwojowi samej agroturystyki, jak również jej otoczenia. Ten rodzaj aktywności angażuje ruch agroturystyczny w rozwój lokalny, dając mu możliwość realizowania własnych celów związanych z wartościami postmaterialistycznymi, przede wszystkim tymi, które dotyczą wiejskiej kultury i krajobrazu.

Podsumowując ten wątek, można powiedzieć, odwołując się do przywołanej typologii Melucciego, że aktywność ruchu agroturystycznego w wymiarze wewnętrznym to budowanie alternatywnego systemu znaczeń, sięgającego jednak przede wszystkim do przeszłości. Z powodu zaniku wielu tradycyjnych elementów wiejskości (między innymi zwyczajów, krajobrazu, produkcji rolnej) ruch agroturystyczny stara się na nowo ożywić te elementy, co czyni go w tym kontekście ruchem konserwatywnym. Na zewnątrz z kolei jego działania są ukierunkowane na kształtowanie świadomości społecznej i eliminowanie negatywnych, zdaniem jego uczestników, skutków modernizacji.

\section{ZAKOŃCZENIE}

Przedstawiony w tym artykule zbiór kwestii dotyczących współczesnych obszarów wiejskich, zwłaszcza procesów zachodzących w ich obrębie, miał uzmysłowić, że stanowią one dogodne środowisko dla wyłaniania się i funkcjonowania nowych ruchów społecznych, a co za tym idzie, teorie charakteryzujące to zja- 
wisko stanowią narzędzie analityczne do opisu i wyjaśnienia niektórych zjawisk obecnych na obszarach wiejskich. Z przeprowadzonych rozważań wynika, że współczesna wieś dysponuje sporym potencjałem dla rozwoju nowych ruchów społecznych. W tym względzie posiada nawet więcej atutów niż miasto. Wartością prowadzonych tu analiz jest nie tylko potwierdzenie użyteczności wspomnianych teorii w odniesieniu do charakterystyki obszarów wiejskich, ale również to, że w efekcie, niejako przy okazji, możemy zakreślić takie pola eksploracji, które pozwolą w przyszłości wnieść również pewien wkład w rozwój samej teorii ruchów społecznych. Mam tu na myśli przede wszystkim dwie kwestie. Po pierwsze, rolę kontekstów instytucjonalnych w generowaniu nowych ruchów społecznych. Zrównoważony model rozwoju obszarów wiejskich czy też przykłady polityk władz państwowych i lokalnych względem wsi i rolnictwa pokazują, że takie odgórne, zinstytucjonalizowane działania mogą stanowić swego rodzaju zachętę dla potencjalnych uczestników ruchów społecznych do ich tworzenia. Po drugie, warto zastanowić się, czy ze względu na bliskość nowych ruchów społecznych życia codziennego, widoczną szczególnie na obszarach wiejskich, ruch społeczny nie jest dla znacznej części społeczności lokalnych niejako naturalną formą egzystencji, a zwłaszcza sposobem adaptacji do zmieniającego się otoczenia. Dzięki ruchowi społecznemu lokalne społeczności wiejskie zyskują niejako kontrolę nad kierunkiem własnego rozwoju. Ruch agroturystyczny przedstawiony w tym artykule jako przykład byłby tego potwierdzeniem. Dzięki niemu w wymiarze indywidualnym ma miejsce obrona indywidualnych tożsamości mieszkańców obszarów wiejskich. Koncentruje się ona na podtrzymywaniu tego, co znika z pejzażu wsi, czyli między innymi małych gospodarstw rolnych, tradycyjnych produktów rolnych, kultury ludowej, ekologicznej żywności czy wiejskiego krajobrazu. Ponadto w wymiarze lokalnym ruch agroturystyczny przyczynia się do budowania sieci współpracy, kapitału społecznego i ludzkiego, jest propagatorem zmian modernizacyjnych pozbawionych negatywnych skutków, a przede wszystkim integruje społeczności lokalne. Ten rodzaj jego aktywności, zwłaszcza orientacja na lokalność, również potwierdzają że możemy go zaliczyć do grona nowych ruchów społecznych. To twierdzenie nie jest jednak bezwarunkowe, ruch agroturystyczny posiada bowiem kilka cech, które mogą podawać w wątpliwość takie jego rozumienie. Mam tu na myśli przede wszystkim stale obecną orientację na zysk, nawet jeśli nie jest ona pierwszoplanowa w skali ruchu, słabe więzi pomiędzy członkami ruchu i niskie poczucie przynależności do niego tam, gdzie agroturystyka nie jest rozwinięta oraz silne determinowanie ruchu przez jego otoczenie instytucjonalne (władze lokalne, ośrodki doradztwa rolniczego, fundusze europejskie). 


\section{BIBLIOGRAFIA}

Beck Colin J. 2013. Ideology. W: The Wiley-Blackwell encyclopaedia of social and political movements, D. Snow, D. della Porta, B. Klandermans, D. McAdam (red.), 586-590. Oxford: Wiley-Blackwell.

Buechler Steven M. 2008. Teorie nowych ruchów społecznych (P. Sadura). W: Dynamika życia społecznego. Współczesne koncepcje ruchów społecznych, K. Gorlach, P. Mooney (red.), 161-188. Warszawa: Wydawnictwo Naukowe Scholar.

della Porta Donatella, Mario Diani. 2009. Ruchy społeczne. Wprowadzenie (A. Sadza). Kraków: Wydawnictwo Uniwersytetu Jagiellońskiego.

Edelman Marc. 1999. Peasants againts globalization. Rural social movement in Costa Rica. Stanford: Stanford University Press.

Foryś Grzegorz. 2008. Dynamika sporu. Protesty rolników w III Rzeczpospolitej. Warszawa: Wydawnictwo Naukowe Scholar.

Foryś Grzegorz. 2016. Gospodarstwa i stowarzyszenia agroturystyczne w Polsce. W poszukiwaniu ruchu społecznego. Warszawa: Wydawnictwo Naukowe Scholar.

Gerlach Luther P. 2001. The structure of social movements: Environmental activism and its opponents. W: Networks and netwars: The future of terror, crime, and militancy, J. Arquilla, D. Ronfeldt (red.), 289-309. Santa Monica: Rand.

Gorlach Krzysztof. 2001. Świat na progu domu. Kraków: Uniwersytet Jagielloński.

Gorlach Krzysztof. 2004. Socjologia obszarów wiejskich. Problemy i perspektywy. Warszawa: Wydawnictwo Naukowe Scholar.

Halamska Maria. 1988. Peasant movements in Poland, 1980-1981: State socialist economy and the mobilization of individual farmers. W: Research in social movements, conflicts and change (10), B. Misztal, L. Kriesberg (red.), 147-160. Greenwich-London: JAI Press Inc.

Jenkins J. Craig. 1982. "Why do peasants rebel? Structural and historical theories of modern peasant rebellions". American Journal of Sociology 88(3): 487-514. Chicago: The Chicago University Press.

Klandermans Bert, Sidney Tarrow. 2008. Mobilizacja w ruchach społecznych: o syntezie koncepcji europejskich i amerykańskich (K. Gorlach). W: Dynamika życia społecznego. Wspótczesne koncepcje ruchów społecznych. K. Gorlach, P. Mooney (red.), 64-97. Warszawa: Wydawnictwo Naukowe Scholar.

Marsden Terry. 2003. The condition of rural sustainability. Assen: Royal Van Gorcum.

Melucci Alberto. 1988. Getting involved: Identity and mobilization in social movements. W: From structure to action: Comparing social movements research across cultures. International social movement research (t. 1). B. Klandermans, H. Kriesi, S. Tarrow (red.), 329-348. Greenwich-London: CT: JAI Press.

Melucci Alberto. 1994. A strange kind of newness: What's "new" in new social movements? W: New social movements. From ideology to identity, E. Larańa, H. Johnston, J.R. Gusfield (red.), 101-130. Philadelphia: Temple University Press.

Melucci Alberto. 1996. Challenging codes: Collective action in the information age. Cambridge: Cambridge University Press.

Migdal Joel S. 1974. Peasants, politics and revolution. Toward political and social change in the third world. Princeton: Princeton University Press.

Mooney Patrick H. 2000. "Specifying the 'rural' in social movement theory". Polish Sociological Review (129): 35-55. 
Mooney Patrick H. 2004. "Democratizing rural economy: Institutional friction, sustainable struggle and the cooperative movement". Rural Sociology 69(1): 76-98. Oxford: Blackwell Publishing Ltd.

Offe Claus. 1995. Nowe ruchy społeczne. Przekraczanie granic polityki instytucjonalnej (P. Karpowicz). W: Władza i społeczeństwo, J. Szczupaczyński (red.), 226-233. Warszawa: Wydawnictwo Naukowe Scholar.

Paige Jeffrey. 1975. Agrarian revolution. New York: Free Press.

Pakulski Jan. 2009. Postmodern social theory. W: The New Blakwell Company to social theory, Bryan S. Turner (red.), 252-280. Oxford: Blackwell Publishing.

Ploeg Jan Douwe van der. 2008. The new peasantries. Struggles for autonomy and sustainability in area of empire and globalization. London: Earthscan.

Reed Matt. 2004. "The mobilization of rural identities and the failure of the rural protest movement in the UK 1996-2001". Space and Polity 8(1): 25-42. London: Carfax Publishing Company.

Scott James C. 1976. The moral economy of peasant. New Haven: Yale University Press.

Scott James C. 1990. Domination and the arts of resistance. Hidden transcripts. New Haven -London: Yale University Press.

Shanin Theodor. 1973. Peasantry as a political factor. W: Peasants and peasant societies, T. Shanin (red.), 238-263. Middlesex: Penguin Books.

Wolf Eric R. 1973. Peasant wars of the twentieth century. New York: Harper and Row.

Grzegorz Foryś

\title{
RURAL AREAS AS A SPACE FOR THE EMERGENCE OF NEW SOCIAL MOVEMENTS. THEORETICAL AND EMPIRICAL IMPLICATIONS
}

\begin{abstract}
One can say that the changes affecting rural areas reflect the processes and phenomena on the level of society as whole. The growing importance of social movements, especially new social movements, which can be observed in contemporary societies, as well as the logic of changes taking place in rural areas, makes it possible to identify the space which these two seemingly distant phenomena share. This article points out the processes which underlie the new social movements coming into existence in rural areas. Simultaneously, the article shows that theories of social movements are useful for analysis of contemporary rural areas. There are two reasons for this approach: Firstly, social movements in modern societies are among the main expressions of empowerment for entire societies, communities, and particular social groups. Thus any new research on social movements deserves attention. Secondly, application of the theory of social movements to analyse the collective behaviour of farmers and rural area residents has been applied in the sociological literature in Poland and elsewhere, usually in the context of collective protest actions of this social group. However, this theory is not widely used to analyse everyday non-protest activities of certain categories of rural residents. The main question is: Is the theory of social movements the right tool for analysing changes in contemporary rural areas?
\end{abstract}

Keywords: rural areas, agritourism, social movements, deactivation, repeasantization 